\title{
Instant Gratification as a Method to Promote Physician Practice Guideline Adherence: A Systematic Review
}

\author{
Neha Deo ${ }^{1}$, Emily Johnson ${ }^{2}$, Kaushik Kancharla ${ }^{3}$, John C. O'Horo ${ }^{4}$, Rahul Kashyap ${ }^{5}$ \\ 1. Medicine, Mayo Clinic Alix School of Medicine, Rochester, USA 2. Medicine, Oklahoma State University, Stillwater, \\ USA 3. Medicine, University of Wisconsin, Madison, USA 4. Infectious Diseases and Pulmonary and Critical Care \\ Medicine, Mayo Clinic, Rochester, USA 5. Critical Care, Mayo Clinic and Foundation, Rochester, USA
}

Corresponding author: Neha Deo, deo.neha@mayo.edu

\begin{abstract}
Inadequate adherence to best practice guidelines may have a negative impact on the processes of critical care and patient outcomes. Instant gratification has been used to modify human behavior in industries such as gaming, lottery, and social media. We hypothesize that, if properly and purposefully utilized, IG can become a successful tool for encouraging best practice guideline adherence among critical care providers. Four major databases were searched with a medial librarian. Covidence application was used to identify studies pertaining to the instant gratification being used to improve provider adherence with best practice guidelines. A total of 712 studies were identified, and, through duplicates removal, title and abstract screening, and full-text screening, a total of 13 studies were included in the final review. The exclusion criteria used included the following: no provider gratification, wrong focus/intervention, wrong study design, patient-focused intervention, not generalizable, and no conclusion. There is a knowledge gap regarding instant gratification utilization to influence practice guideline adherence among providers. The intervention functions of the Behavior Change Wheel (BCW) were evident, especially 'persuasion' and 'incentivization', which are most pertinent to our field. The restorative process that promotes positive reinforcement can be a potential solution for alleviating inadequacies in guideline adherence. Examining interventions based on functions of the BCW has shown that an instant gratification process may have the potential in altering critical care providers' behavior and improving guideline adherence. This review is the first step towards creating smart algorithms to instantly alert providers for their actions compliant with best practices. Developing, testing, and validating the algorithms will be the next several steps.
\end{abstract}

Received 07/10/2020 Review began 07/14/2020 Review ended 07/15/2020 Published 07/25/2020

() Copyright 2020 Deo et al. This is an open access article distributed under the terms of the Creative Commons Attribution License CC-BY 4.0., which permits unrestricted use, distribution, and reproduction in any medium, provided the original author and source are credited.
Categories: Quality Improvement, Public Health, Healthcare Technology

Keywords: physician guideline adherence, behavior change wheel, instant gratification, behavioral intervention

\section{Introduction And Background}

Utilizing physician adherence guidelines can decrease healthcare costs, improve health outcomes for patients, and standardize patient care [1]. However, lack of physician guideline adherence is one of the most prevalent problems in the healthcare system today [2]. Inadequate adherence results in nearly 269 million dollars wasted in treatments that are not beneficial to patients' health [3]. More importantly, noncompliance with treatment guidelines can also negatively affect a patient's health [2]. However, external barriers such as cost, and internal barriers, lack of knowledge, may make it challenging for healthcare providers to follow guidelines [1]. This may result in a deterioration in the quality of patient care [4].

Recent literature has explored the implementation of behavioral interventions that target patient-centered care [2]. Many of these interventions are based on techniques that have been effective in encouraging providers to follow recommended guidelines. However, it can be difficult to obtain physician buy-in for partaking, especially of those who are not inclined to [5]. Therefore, the development of an effective behavioral intervention requires a rigorous design process that addresses underlying issues that pose a barrier to guideline adherence [6].

One proposed method in developing an effective behavioral intervention is implementing instant gratification. As a phenomenon, it is usually associated with a negative connotation. Instant gratification can be utilized to positively reinforce behaviors that follow guidelines. Electronic health records (EHRs) could be a potential avenue to implement this strategy. The Clinical Decision Support Systems (CDSS) programs improve the quality of care for patients by suggesting additional assessments or test recommendations that the clinician can consider [7]. Recent studies have shown that this tool has been effective in evidence-based practice while also providing an additional resource for knowledge and support [7]. Utilization of CDSS is currently incentivized in the U.S as policy makers believe that the program can cut costs, provide timely reminders, and therefore improve quality of care [4].

In order to create a successful intervention that utilizes instant gratification and encourages adherence to guidelines, it is important to utilize the Behavior Change Wheel (BCW). BCW is intended to develop an 
intervention that analyzes the behavior in question [8]. The underlying hypothesis is that there is a relationship between one's capability $(\mathrm{C})$, opportunity $(\mathrm{O})$, and motivation $(\mathrm{M})$ which explains why a behavior (B) is or is not observed (COM-B) [9]. COM-B could be used to investigate factors that elicit the desired behavior and therefore develop an effective intervention based on clinical context [10].

To date, there has been no behavioral intervention that utilizes instant gratification to improve physician guideline adherence. The purpose of this review is to show that, if properly and purposefully utilized, instant gratification can become a successful tool for encouraging targeted actions and behaviors.

\section{Review}

\section{Methods}

We performed a literature review on instant gratification and behavioral interventions in medicine. We provided search terms to a librarian. The librarian searched in four databases (Medline, Embase, CINAHL, Web of Science). The Covidence application was used to identify studies pertaining to using instant gratification to improve physician adherence with practice guidelines. Publications were restricted between January 2009 and December 2018. The primary search term included one of the following: instant gratification, reward, immediate gratification, gratification, short-term gratification, pleasure, impulse, temptation, urge, motivation, or fulfillment. A secondary term, which accompanied the primary term, included one of the following: doctor, nurse, health care providers, healthcare, compliance, treatment compliance, practices, best practices, hospital, dopamine, prefrontal cortex, serotonin, ventral tegmental area, positive reinforcement. A total of 712 records were identified, and, through duplicate screening, title and abstract screening, and full-text screening, 13 studies were included in the final review (Figure 1). The exclusion criteria used included the following: no provider gratification, wrong focus/intervention, wrong study design, patient-focused intervention, not generalizable, and no conclusion.

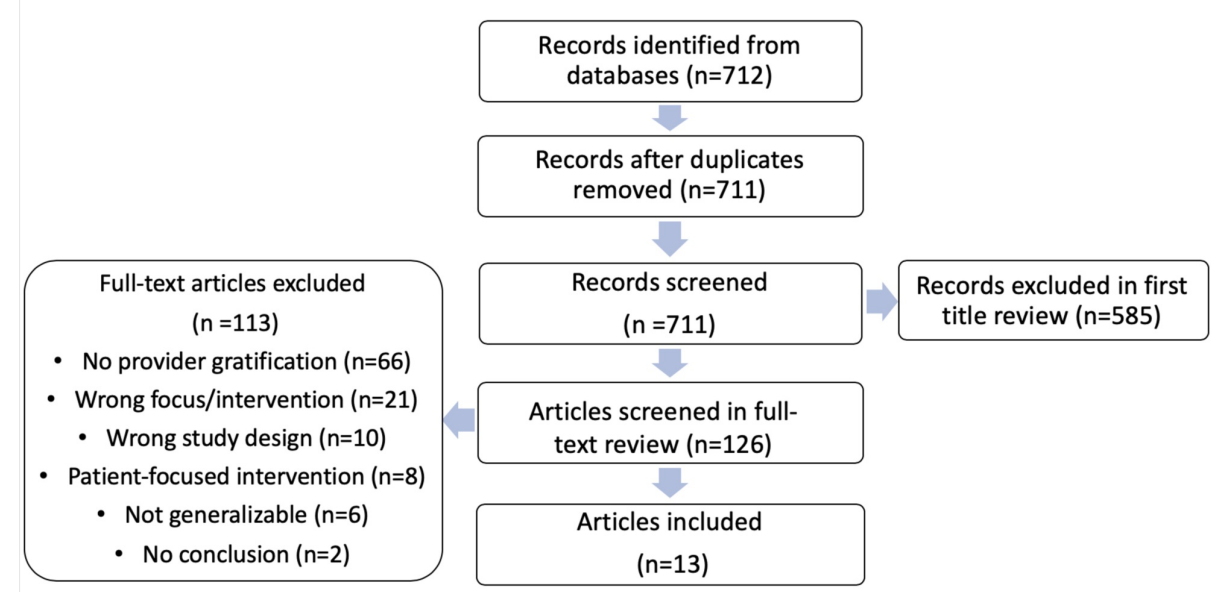

FIGURE 1: Flowchart of Identification, Screening Exclusion, and Inclusion

\section{Results}

The 13 included articles provided a wide variety of information pertaining to the study subject (Table 1). The studies gave information on many of the intervention functions of the behavior change wheel (BCW), especially persuasion and incentivization, which are most relevant to the topic (Figure 2). Intervention development and implementation were both detailed and analyzed, along with potential barriers to interventions.

\begin{tabular}{|c|c|c|c|c|}
\hline Author & Study Title, Year & ML Methods & Results & $\begin{array}{l}\text { Outcomes/Impact on } \\
\text { Healthcare Delivery }\end{array}$ \\
\hline $\begin{array}{l}\text { Goud et } \\
\text { al. }[1]\end{array}$ & $\begin{array}{l}\text { The effect of } \\
\text { computerized decision } \\
\text { support on barriers to } \\
\text { guideline implementation: }\end{array}$ & $\begin{array}{l}\text { Semi-structured interviews were } \\
\text { performed with healthcare } \\
\text { professionals who had utilized } \\
\text { CARDSS (Cardiac } \\
\text { Rehabilitation Decision Support }\end{array}$ & $\begin{array}{l}\text { Interviews ranged from } 30 \text { - } \\
60 \text { minutes. Internal } \\
\text { barriers, such as lack of } \\
\text { familiarity, preference for } \\
\text { previous methodologies, } \\
\text { and lack of agreement }\end{array}$ & $\begin{array}{l}\text { Although utilization of a } \\
\text { computerized decision- } \\
\text { making support system } \\
\text { improved guideline } \\
\text { implementation, one must }\end{array}$ \\
\hline
\end{tabular}




\begin{tabular}{|c|c|c|c|c|}
\hline & $\begin{array}{l}\text { A qualitative study in } \\
\text { outpatient cardiac } \\
\text { rehabilitation, } 2010\end{array}$ & $\begin{array}{l}\text { System) for more than } 1 \text { year. } \\
\text { Professionals from } 25 \text { clinics } \\
\text { were invited to join the study. }\end{array}$ & $\begin{array}{l}\text { existed. External barriers, } \\
\text { such as lack of resources } \\
\text { or logistical challenges } \\
\text { were a hindrance. }\end{array}$ & $\begin{array}{l}\text { evaluate barriers that may } \\
\text { make it difficult for } \\
\text { healthcare providers to } \\
\text { use this system. }\end{array}$ \\
\hline $\begin{array}{l}\text { Chauhan et } \\
\text { al. [2] }\end{array}$ & $\begin{array}{l}\text { Behavior change } \\
\text { interventions and policies } \\
\text { influencing primary } \\
\text { healthcare professionals' } \\
\text { practice-an overview of } \\
\text { reviews, } 2017\end{array}$ & $\begin{array}{l}\text { A systematic review was } \\
\text { performed that summarized the } \\
\text { effectiveness of different } \\
\text { behavioral change } \\
\text { interventions. }\end{array}$ & $\begin{array}{l}\text { Clinical decision support } \\
\text { systems, multi-faceted } \\
\text { teams, and environmental } \\
\text { restructuring were found to } \\
\text { all have positive effects on } \\
\text { adherence to guidelines. }\end{array}$ & $\begin{array}{l}\text { Adherence to guidelines } \\
\text { for providers requires a } \\
\text { multi-faceted approach } \\
\text { that targets effective } \\
\text { training, Al systems, and } \\
\text { an integrated community } \\
\text { with other healthcare } \\
\text { workers. }\end{array}$ \\
\hline $\begin{array}{l}\text { Dixon et al. } \\
\text { [4] }\end{array}$ & $\begin{array}{l}\text { Health care providers } \\
\text { perceptions of use and } \\
\text { influence of clinical } \\
\text { decision support } \\
\text { reminders: qualitative } \\
\text { study following a } \\
\text { randomized trial to } \\
\text { improve HPV vaccination } \\
\text { rates, } 2017\end{array}$ & $\begin{array}{l}\text { Semi-structured interviews with } \\
\text { providers aimed to investigate } \\
\text { the effectiveness of CDS } \\
\text { (Computer-based Clinical } \\
\text { Support) programs in pediatric } \\
\text { centers that encouraged HPV } \\
\text { vaccination. }\end{array}$ & $\begin{array}{l}\text { Providers recalled seeing } \\
\text { the notification, however a } \\
\text { majority stated that they } \\
\text { were not influenced by the } \\
\text { notification. However, HPV } \\
\text { rates increased during this } \\
\text { intervention. }\end{array}$ & $\begin{array}{l}\text { CDS has the potential of } \\
\text { influencing provider } \\
\text { behaviors, although they } \\
\text { may not perceive them to } \\
\text { be significant. }\end{array}$ \\
\hline $\begin{array}{l}\text { Curran et al. } \\
{[5]}\end{array}$ & $\begin{array}{l}\text { Implementation } \\
\text { strategies to promote } \\
\text { provider behavior change } \\
\text { in emergency } \\
\text { departments, }\end{array}$ & $\begin{array}{l}\text { A systematic review was } \\
\text { performed that strategies that } \\
\text { were implemented to change } \\
\text { physician behavior in the } \\
\text { emergency department. }\end{array}$ & $\begin{array}{l}\text { Most strategies were multi- } \\
\text { faceted, focusing on } \\
\text { educational material and } \\
\text { reminders. }\end{array}$ & $\begin{array}{l}\text { In order to promote } \\
\text { positive behavioral } \\
\text { changes in ED physicians, } \\
\text { interventions should be } \\
\text { intentional and } \\
\text { comprehensive. }\end{array}$ \\
\hline $\begin{array}{l}\text { Creupelandt } \\
\text { et al. [6] }\end{array}$ & $\begin{array}{l}\text { Teaching young GPs to } \\
\text { cope with psychosocial } \\
\text { consultations without } \\
\text { prescribing: a durable } \\
\text { impact of an e-module on } \\
\text { determinants of } \\
\text { benzodiazepines } \\
\text { prescribing, } 2017\end{array}$ & $\begin{array}{l}\text { GP's, who were in vocational } \\
\text { training, were offered to use an } \\
\text { e-module that encouraged } \\
\text { psychological support over use } \\
\text { of benzodiazepines. GP's were } \\
\text { given an assessment at } \\
\text { baseline, } 3 \text { months, and } 12 \\
\text { months that asked about their } \\
\text { perceptions of the program. }\end{array}$ & $\begin{array}{l}\text { GP's underwent desirable } \\
\text { changes related to their } \\
\text { self-efficacy and were } \\
\text { more likely to adhere to } \\
\text { guidelines. }\end{array}$ & $\begin{array}{l}\text { E-modules have the } \\
\text { potential to encourage } \\
\text { adherence to guidelines, } \\
\text { leading to better } \\
\text { prescribing practices and } \\
\text { less reliance on } \\
\text { pharmaceutical drugs. }\end{array}$ \\
\hline $\begin{array}{l}\text { Durieux et } \\
\text { al. [7] }\end{array}$ & $\begin{array}{l}\text { A Clinical Decision } \\
\text { Support System for } \\
\text { Prevention of Venous } \\
\text { Thromboembolism, } 2000\end{array}$ & $\begin{array}{l}\text { Providers used a CDSS } \\
\text { (Computer-based decision } \\
\text { support system) that provided } \\
\text { notifications when seeing } \\
\text { patients at risk for venous } \\
\text { thromboembolism. }\end{array}$ & $\begin{array}{l}\text { Physicians had an } 82.8 \% \\
\text { compliance to guidelines in } \\
\text { control groups and } 94.9 \% \\
\text { in the intervention group. } \\
\text { After the intervention, } \\
\text { reversion to original } \\
\text { compliance was observed. }\end{array}$ & $\begin{array}{l}\text { Integration of CDSS } \\
\text { changed provider } \\
\text { behavior, however it is } \\
\text { clear that ongoing use of } \\
\text { the CDSS is integral to } \\
\text { continuing those } \\
\text { behaviors. }\end{array}$ \\
\hline $\begin{array}{l}\text { Backman et } \\
\text { al. [8] }\end{array}$ & $\begin{array}{l}\text { The development of an } \\
\text { intervention to promote } \\
\text { adherence to national } \\
\text { guidelines for suspected } \\
\text { viral encephalitis, } 2015\end{array}$ & $\begin{array}{l}\text { Semi-structured interviews were } \\
\text { performed to evaluate barriers } \\
\text { to treating patients with viral } \\
\text { encephalitis. A suggested } \\
\text { intervention was developed. } \\
\text { Behavior change techniques } \\
\text { were emphasized. }\end{array}$ & $\begin{array}{l}\text { Barriers such as } \\
\text { knowledge/skills related to } \\
\text { lumbar punctures and } \\
\text { organizational resource } \\
\text { constraints were } \\
\text { highlighted. A core } \\
\text { package of suggested } \\
\text { interventions were } \\
\text { delivered. }\end{array}$ & $\begin{array}{l}\text { This intervention } \\
\text { highlighted specific } \\
\text { factors that could } \\
\text { influence physician } \\
\text { behaviors and evaluation } \\
\text { when treating patients. }\end{array}$ \\
\hline $\begin{array}{l}\text { Loft et al. } \\
\text { [9] }\end{array}$ & $\begin{array}{l}\text { Strengthening the role } \\
\text { and functions of nursing } \\
\text { staff in inpatient stroke } \\
\text { rehabilitation: developing } \\
\text { a complex intervention } \\
\text { using the Behaviour } \\
\text { Change Wheel, } 2017\end{array}$ & $\begin{array}{l}\text { The behavior change wheel } \\
\text { (BCW) was utilized in order to } \\
\text { develop an intervention that } \\
\text { helps clarify and strengthen the } \\
\text { role of nurses in cardiac } \\
\text { rehabilitation centers. }\end{array}$ & $\begin{array}{l}\text { An intervention that helped } \\
\text { strengthen the functionality } \\
\text { of the nurses' role was } \\
\text { developed, and include } \\
\text { (but not limited to) } \\
\text { interdisciplinary teamwork, } \\
\text { training, and educational } \\
\text { material. }\end{array}$ & $\begin{array}{l}\text { This intervention was } \\
\text { executed in the hospital } \\
\text { setting and is currently } \\
\text { awaiting results. }\end{array}$ \\
\hline
\end{tabular}




\begin{tabular}{|c|c|c|c|c|}
\hline $\begin{array}{l}\text { Horppu et } \\
\text { al. [10] }\end{array}$ & $\begin{array}{l}\text { Theoretical Domains } \\
\text { Framework and the } \\
\text { Behavior Change Wheel } \\
\text { to Understand } \\
\text { Physicians' Behaviors } \\
\text { and Behavior Change in } \\
\text { Using Temporary Work } \\
\text { Modifications for Return } \\
\text { to Work: A Qualitative } \\
\text { Study, } 2017\end{array}$ & $\begin{array}{l}\text { The behavior change wheel } \\
\text { (BCW) was used as a model to } \\
\text { understand physician behaviors } \\
\text { when returning to work. } \\
\text { Participants participated in } \\
\text { focus group interviews relating } \\
\text { to temporary work } \\
\text { modifications (TWM) when } \\
\text { returning to work after an } \\
\text { extended period of time. }\end{array}$ & $\begin{array}{l}\text { Promoting desired } \\
\text { behaviors were more likely } \\
\text { when participants were } \\
\text { personally motivated and } \\
\text { when resources were not } \\
\text { constrained in the } \\
\text { workplace. When TWM } \\
\text { were applied, physicians } \\
\text { were more likely to perform } \\
\text { well. }\end{array}$ & $\begin{array}{l}\text { TWM's are a valuable tool } \\
\text { in promoting positive } \\
\text { behaviors in physicians } \\
\text { that recently have } \\
\text { returned to work. In order } \\
\text { to positively influence } \\
\text { behaviors, systemic } \\
\text { changes in the institution } \\
\text { should be geared towards } \\
\text { support for providers. }\end{array}$ \\
\hline $\begin{array}{l}\text { Moe-Byrne } \\
\text { et al. [11] }\end{array}$ & $\begin{array}{l}\text { Behavior change } \\
\text { interventions to promote } \\
\text { prescribing of generic } \\
\text { drugs: a rapid evidence } \\
\text { synthesis and systematic } \\
\text { review, } 2014\end{array}$ & $\begin{array}{l}\text { A systematic review was } \\
\text { performed to evaluate } \\
\text { behavioral interventions that } \\
\text { were designed to encourage } \\
\text { generic drug prescriptions. }\end{array}$ & $\begin{array}{l}\text { Two studies showed } \\
\text { increases in generic } \\
\text { prescribing when provided } \\
\text { appropriate education. } \\
\text { Two others showed } \\
\text { promise for electronic } \\
\text { subscription. One review } \\
\text { highlighted financial } \\
\text { incentives. Limited results } \\
\text { were found. }\end{array}$ & $\begin{array}{l}\text { Limited evidence is } \\
\text { available, however } \\
\text { financial incentives and } \\
\text { education could } \\
\text { potentially influence } \\
\text { physician behavior to } \\
\text { prescribe generic drugs. }\end{array}$ \\
\hline $\begin{array}{l}\text { Sinnot et al. } \\
\text { [12] }\end{array}$ & $\begin{array}{l}\text { Improving medication } \\
\text { management in } \\
\text { multimorbidity: } \\
\text { development of the } \\
\text { Multimorbidity } \\
\text { Collaborative Medication } \\
\text { Review And Decision } \\
\text { Making (MY COMRADE) } \\
\text { intervention using the } \\
\text { Behavior Change Wheel, } \\
2015\end{array}$ & $\begin{array}{l}\text { A systematic review was } \\
\text { performed, and a qualitative } \\
\text { analysis was completed. A } \\
\text { focused behavior analysis } \\
\text { utilizing the behavior change } \\
\text { wheel (BCW) was used to } \\
\text { explain why physicians were } \\
\text { not actively reviewing } \\
\text { medications with patients, and } \\
\text { instead following the "status } \\
\text { quo". }\end{array}$ & $\begin{array}{l}\text { Environmental } \\
\text { restructuring, } \\
\text { incentivization, and } \\
\text { enablement were identified } \\
\text { as important components } \\
\text { to increasing medication } \\
\text { review, as well as } \\
\text { reviewing medications with } \\
\text { another GP. }\end{array}$ & $\begin{array}{l}\text { The BCW can be used to } \\
\text { suggest potential } \\
\text { solutions for behavioral } \\
\text { changes in physicians, } \\
\text { particularly with } \\
\text { interventions related to } \\
\text { multimorbidity. }\end{array}$ \\
\hline $\begin{array}{l}\text { Pedersen et } \\
\text { al. [13] }\end{array}$ & $\begin{array}{l}\text { Can external } \\
\text { interventions crowd in } \\
\text { intrinsic motivation? A } \\
\text { cluster randomised field } \\
\text { experiment on mandatory } \\
\text { accreditation of general } \\
\text { practice in Denmark, } \\
2018\end{array}$ & $\begin{array}{l}\text { A survey was distributed to } \\
\text { participants that asked about } \\
\text { the perception of accreditation } \\
\text { of general practices in } \\
\text { Denmark. Researchers } \\
\text { investigated if external } \\
\text { interventions could impair } \\
\text { physician's intrinsic motivation. }\end{array}$ & $\begin{array}{l}\text { GP's viewed the } \\
\text { accreditation process as } \\
\text { an opportunity for the } \\
\text { government to control their } \\
\text { practice. Those who } \\
\text { viewed it more positively } \\
\text { had a higher intrinsic } \\
\text { motivation than those who } \\
\text { did not. }\end{array}$ & $\begin{array}{l}\text { Some external } \\
\text { interventions can motivate } \\
\text { physicians towards quality } \\
\text { improvement. However, } \\
\text { they must see it as a } \\
\text { positive factor first. }\end{array}$ \\
\hline $\begin{array}{l}\text { Ryan et al. } \\
{[14]}\end{array}$ & $\begin{array}{l}\text { The Intended and } \\
\text { Unintended } \\
\text { Consequences of Quality } \\
\text { Improvement } \\
\text { Interventions for Small } \\
\text { Practices in a } \\
\text { Community-based } \\
\text { Electronic Health Record } \\
\text { Implementation Project, } \\
2014\end{array}$ & $\begin{array}{l}\text { A community based EHR } \\
\text { program was implemented that } \\
\text { focused on clinical decision } \\
\text { making. The program either } \\
\text { provided feedback, or financial } \\
\text { incentives, each time a criterion } \\
\text { was met (such as appropriate } \\
\text { treatment). }\end{array}$ & $\begin{array}{l}\text { Financial incentives were } \\
\text { consistently reported with } \\
\text { higher performance. Non- } \\
\text { Incentivized measures } \\
\text { were associated with lower } \\
\text { performance. Technical } \\
\text { assistance improved } \\
\text { performance measures as } \\
\text { well (particularly when } \\
\text { incentivized) }\end{array}$ & $\begin{array}{l}\text { Financial incentives and } \\
\text { technical support can } \\
\text { improve performance } \\
\text { outcomes in EHR } \\
\text { programs that are } \\
\text { designed to support } \\
\text { clinical decision making. }\end{array}$ \\
\hline
\end{tabular}




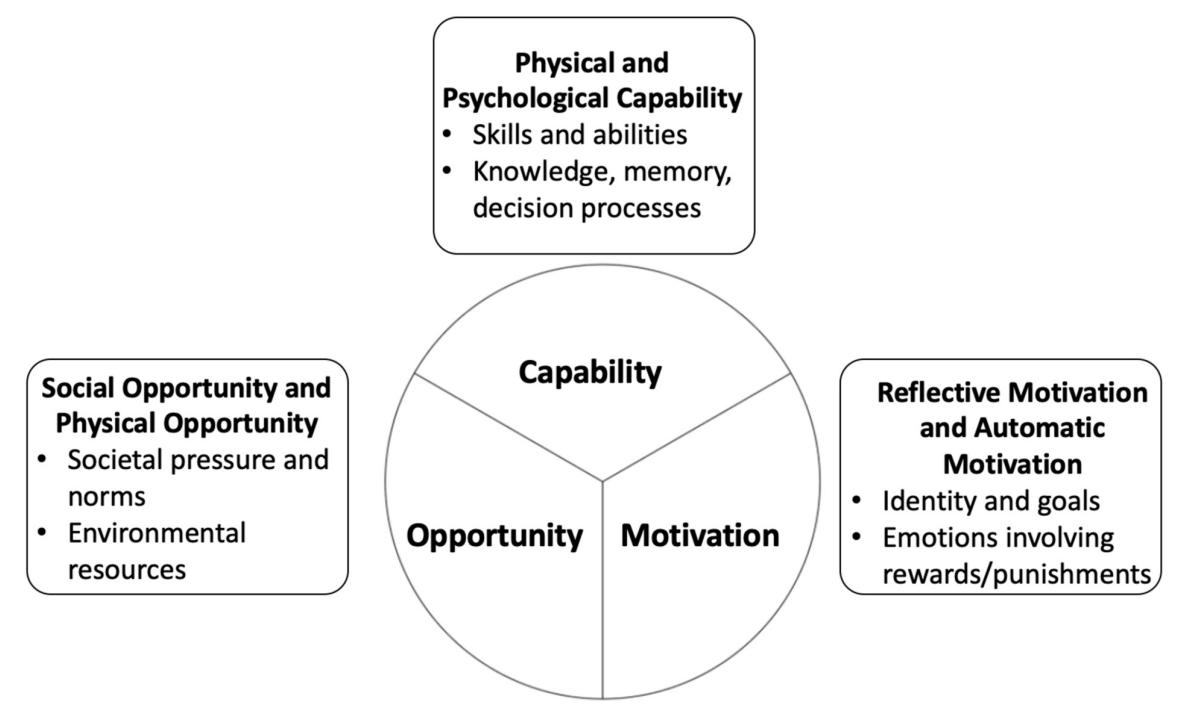

FIGURE 2: Behavior Change Wheel

We identified 712 records from the literature search and narrowed the results to 13 articles. Of the 13 studies, three studies were reviews of the current literature of behavioral interventions in medicine $[2,5,11]$. 4 studies utilized the COM-B approach to rigorously evaluate the proposed behavioral intervention for each study $[8-10,12]$. Another 4 studies tested CDSS programs or modules and measured the frequency of guideline adherence or changes in provider behavior $[1,4,6,7]$. A total of 7 studies discuss intrinsic or extrinsic factors in healthcare that influence provider motivation $[2,8,10-14]$.

\section{COM-B Approach}

A total of 4 studies focused on the COM-B model to enhance their behavioral intervention. Utilizing semistructured interviews allowed researchers to evaluate the current challenges of providers [8]. Participants are able to express uncertainties related to providing care [8]. Two studies cited that evaluating the clinical environment in terms of resources allowed researchers to create an intervention that addressed these barriers $[8,12]$. Action planning increased the likelihood that a provider could realistically implement the behavioral intervention in their own clinic [12]. COM-B allowed for researchers to identify the motivations and capabilities of their cohort before designing the intervention $[9,10]$. Identifying the motivations of individuals was important in enabling providers to elicit the desired behavior $[9,10,12]$.

\section{CDSS Programs}

Four studies utilized CDSS programs or educational modules in the healthcare setting and measured changes in guideline compliance. Providers are likely to notice the notifications that CDSS provides, however they may not perceive it as influencing their behavior - although results may suggest that compliance increased [4]. One study suggested that CDSS increases compliance as it provides clarifications on guidelines for treatment [1]. AI programs increased the frequency of prescribing according to guidelines [6,7]. There was also an increase in self-efficacy in providers when utilizing e-modules [6]. One study noted that if there is a lack of resources available to the provider, online programs will not help compliance [1].

\section{Factors Influencing Motivation}

A total of 7 studies explored the influence of intrinsic and extrinsic motivation and changes in behavior. Providing financial incentives led to an increase in the quality of care $[11,14]$. Addressing external factors, such as lack of experience with procedures, or environmental structuring of healthcare professionals in teams, can influence international motivation and thus performance $[2,8,10,12,13]$. Organizations that implement audit and feedback programs observe a modest increase in desired behaviors [11].

\section{Discussion}

We evaluated the current behavioral interventions that have observed an increase in desired behaviors in healthcare providers. Although there are no studies that have investigated the correlation between instant gratification and guideline compliance, there is plenty of data to suggest that providers can elicit desired behaviors if the right tools are applied. Behavioral interventions utilizing the BCW showed promising results that elicited desirable changes in providers. The success of the BCW comes with its primary goal to evaluate the intervention thoroughly before execution, such as identifying participant motivations and barriers 
$[9,10,12]$. Providers that utilized CDSS programs were more likely to adhere to the guidelines and improved prescribing practices. Frequent reminders were a valuable tool for physicians as they provided suggestions for tests or treatment [1]. Individuals who are more motivated to take part in behavioral change techniques are more likely to exhibit the desired behavior [12]. This is fueled by the person's intrinsic motivation to change. External motivations, such as financial gain, can play a factor, however, it varies from person to person [14].

\section{BCW Interventions}

The BCW is a valuable tool that allows researchers to conceptualize targeted behavioral changes, apply the proposed change through an intervention, and then evaluate the results (BCW 1). Proposing an intervention using this method allows researchers to evaluate barriers that would otherwise prevent desirable outcomes $[9,10,15]$. By utilizing the COM-B method, investigators can develop a strong framework that can focus on a targeted behavior and the outcomes [3,8].

Jackson et al. (2014) encourage the COM-B method for behavioral outcomes related to adherence as it considers external factors that other methods do not consider [3,9]. Behavioral changes in medication adherence can be influenced by a number of external factors such as limited resources and access to healthcare can influence adherence [3,12]. Investigators emphasized the importance of evaluating factors that result in non-compliance through existing literature before executing the intervention [3].

Stewart et al. (2019) executed a behavioral intervention which aimed to increase the competency of providers in stroke rehabilitation clinics using the BCW [15]. Participants were found to retain competency in their role after training, were more enthusiastic in their roles, and were more confident in their skills [16]. Long term behavioral changes were observed, as providers were able to recall the learning that was done during the intervention, and felt more satisfied in their role [16]. Investigators stressed that active engagement on behalf of the participants was key to desirable outcomes [16].

Gambling Industry

The gambling industry is a useful comparison for evaluating the potential of instant gratification to elicit behavioral changes. Casinos and lottery games use systems in place to encourage the repetition of gambling behaviors [17]. This is because individuals are hypersensitive to rewards. Mental representations can make gambling more attractive to individuals, and those who have more positive implicit attitudes to gambling are likely to play [17]. By providing spaced intervals in which participants receive satisfaction, addictive behavior is elicited [18].

There is an attractiveness component to uncertain rewards. Intermittent wins and losses are integral to continued play as there is a stronger behavioral response to play when participants cannot predict when rewards come up [17]. Thus, intermittent reward schedules are more resistant to extinction [17]. Players will generally accept more frequent, smaller rewards over larger, longer to wait rewards as it provides a feeling of satisfaction and subjective feelings of pleasure [17,19]. Frequently occurring feelings of pleasure can encourage players to continue gambling, which can soon become a learned association [17]. Some individuals participate in gambling in hopes of monetary gain, however, it is the unpredictability of rewards that motivates one to continue playing [20].

\section{Social Media}

Social media usage is largely influenced by gratification, which leads to increases in media usage [21]. There is immediate satisfaction due to content generation and gaining recognition from other users [22], correlating with a positive relationship with social media use [23]. Pleasurable satisfaction can lead to addictive behavior and habit formation. Most users will utilize an online activity to seek gratification, which soon leads to a pattern of conditioned behaviors [24].

Most social media content is created on the basis of motivational factors such as entertainment or information-seeking [22]. If there are greater feelings of satisfaction, individuals are more likely to repeat the same activity [21]. Although specific gratifications are determined by different personality traits [22], once a user develops a habit through gratification, one can expect a self-feedback system in which the user will continue to utilize that medium [23].

\section{Strengths}

This study provides valuable information that suggests instant gratification can be utilized to increase guideline adherence in providers. The BCW has the potential to create an intervention that evaluates the needs of the targeted population while also addressing barriers to a specific behavioral response.

Second, the implementation of CDSS programs that suggest recommendations for patient care is highly 
underutilized, and this paper highlights the effectiveness of these systems. There is a plethora of data to suggest positive outcomes for providers that utilize CDSS programs to improve patient care, and if paired with instant gratification, there is the potential to make these outcomes sustainable in the long term.

Our study also highlights the importance of motivation in behavioral change. If participants are motivated to participate in behavioral interventions, they are more likely to meet the desired outcomes [16]. An important consideration during the pre-intervention phase is to investigate barriers that prevent the desired behavior from being observed. This likely hinders motivation.

Weaknesses

There are several weaknesses that exist in our study. First, there is limited data related to instant gratification in the healthcare setting. Although effective with developed gambling behaviors and with social media usage, these industries heavily rely on developing a habit in the form of an addiction. Many of these addictions develop implicitly. However, we are aiming to create a sustainable behavioral change where providers are intentionally motivated to improve patient care.

Another limitation is that none of our evaluated studies investigated instant gratification. Rather, they evaluated interventions that targeted a certain behavior, and reported outcomes. There is limited information related to instant gratification specifically. Many studies investigate gratification on a broader basis. The effectiveness of instant gratification in behavioral interventions is currently unknown.

\section{Conclusions}

In conclusion, there is the potential for instant gratification to encourage guideline compliance with healthcare providers. The BCW is a valuable tool that evaluates the barriers and motivations of individuals before developing an effective behavioral intervention. Much of the success of a behavioral intervention comes from the participant's motivation to elicit change. CDSS programs can influence provider behaviors by providing continual reminders to the user. If utilized with instant gratification, it could positively reinforce desired behaviors by providing encouragement to providers. This has the potential to increase guideline compliance if utilized correctly.

\section{Additional Information \\ Disclosures}

Conflicts of interest: In compliance with the ICMJE uniform disclosure form, all authors declare the following: Payment/services info: All authors have declared that no financial support was received from any organization for the submitted work. Financial relationships: All authors have declared that they have no financial relationships at present or within the previous three years with any organizations that might have an interest in the submitted work. Other relationships: All authors have declared that there are no other relationships or activities that could appear to have influenced the submitted work.

\section{References}

1. Goud R, van Engen-Verheul M, de Keizer NF, Bal R, Hasman A, Hellemans IM, Peek N: The effect of computerized decision support on barriers to guideline implementation: a qualitative study in outpatient cardiac rehabilitation. Int J Med Inform. 2010, 79:430-437. 10.1016/j.ijmedinf.2010.03.001

2. Chauhan BF, Jeyaraman MM, Mann AS, et al.: Behavior change interventions and policies influencing primary healthcare professionals' practice-an overview of reviews. Implement Sci. 2017, 12:3. 10.1186/s13012-016-0538-8

3. Jackson C, Eliasson L, Barber N, Weinman J: Applying COM-B to medication adherence. Eur Health Psychol. 2014, 16:7-17.

4. Dixon BE, Kasting ML, Wilson S, Kulkarni A, Zimet GD, Downs SM: Health care providers' perceptions of use and influence of clinical decision support reminders: qualitative study following a randomized trial to improve HPV vaccination rates. BMC Med Inform Decis Mak. 2017, 17:119. 10.1186/s12911-017-0521-6

5. de Wit K, Curran J, Thoma B, et al.: Review of implementation strategies to change healthcare provider behaviour in the emergency department. CJEM. 2018, 20:453-460. 10.1017/cem.2017.432

6. Creupelandt H, Anthierens S, Habraken H, Declercq T, Sirdifield C, Siriwardena AN, Christiaens T: Teaching young GPs to cope with psychosocial consultations without prescribing: a durable impact of an e-module on determinants of benzodiazepines prescribing. BMC Med Educ. 2017, 17:259. 10.1186/s12909-017-1100-3

7. Durieux P, Nizard R, Ravaud P, Mounier N, Lepage E.: A clinical decision support system for prevention of venous thromboembolism: effect on physician behavior. JAMA. 2000, 283:2816-2821. 10.1001/jama.283.21.2816

8. Backman R, Foy R, Michael BD, Defres S, Kneen R, Solomon T: The development of an intervention to promote adherence to national guidelines for suspected viral encephalitis. Implement Sci. 2015, 10:37. 10.1186/s13012-015-0224-2

9. Loft MI, Martinsen B, Esbensen BA, Mathiesen LL, Iversen HK, Poulsen I: Strengthening the role and functions of nursing staff in inpatient stroke rehabilitation: developing a complex intervention using the Behaviour Change Wheel. Int I Oual Stud Health Well-being. 2017, 12:1. 10.1080/17482631.2017.1392218

10. Horppu R, Martimo KP, MacEachen E, Lallukka T, Viikari-Juntura E: Application of the theoretical domains 
framework and the behaviour change wheel to understand physicians' behaviors and behavior change in using temporary work modifications for return to work: a qualitative study. J Occup Rehabil. 2018, 28:135146. 10.1007/s10926-017-9706-1

11. Moe-Byrne T, Chambers D, Harden M, McDaid C: Behaviour change interventions to promote prescribing of generic drugs: a rapid evidence synthesis and systematic review. BMJ Open. 2014, 4:e004623. 10.1136/bmjopen-2013-004623

12. Sinnott C, Mercer SW, Payne RA, Duerden M, Bradley CP, Byrne M: Improving medication management in multimorbidity: development of the MultimorbiditY COllaborative Medication Review And DEcision Making (MY COMRADE) intervention using the Behaviour Change Wheel. Implement Sci. 2015, 10:132. 10.1186/s13012-015-0322-1

13. Pedersen LB, Andersen MKK, Jensen UT, Waldorff FB, Jacobsen CB: Can external interventions crowd in intrinsic motivation? A cluster randomised field experiment on mandatory accreditation of general practice in Denmark. Soc Sci Med. 2018, 211:224-233. 10.1016/j.socscimed.2018.06.023

14. Ryan AM, McCullough CM, Shih SC, Wang JJ, Ryan MS, Casalino LP: The intended and unintended consequences of quality improvement interventions for small practices in a community-based electronic health record implementation project. Med Care. 2014, 52:826-832. 10.1097/MLR.0000000000000186

15. Stewart C, Power E, McCluskey A, Kuys S: Development of a participatory, tailored behaviour change intervention to increase active practice during inpatient stroke rehabilitation. Disabil Rehabil. 2019, 1-9. 10.1080/09638288.2019.1597178

16. Ross AJ, Reedy GB, Roots A, Jaye P, Birns J: Evaluating multisite multiprofessional simulation training for a hyperacute stroke service using the Behaviour Change Wheel. BMC Med Educ. 2015, 15:143. 10.1186/s12909-015-0423-1

17. Brevers D, Noel X: Pathological gambling and the loss of willpower: a neurocognitive perspective . Socioaffect Neurosci Psychol. 2013, 3:1. 10.3402/snp.v3i0.21592

18. Gaher RM, Hahn AM, Shishido H, Simons JS, Gaster S: Associations between sensitivity to punishment, sensitivity to reward, and gambling. Addict Behav. 2015, 42:180-184. 10.1016/j.addbeh.2014.11.014

19. Bialaszek W, Gaik M, McGoun E, Zielonka P: Impulsive people have a compulsion for immediate gratification-certain or uncertain. Front Psychol. 2015, 6:515. 10.3389/fpsyg.2015.00515

20. Anselme P, Robinson MJ: What motivates gambling behavior? Insight into dopamine's role . Front Behav Neurosci. 2013, 7:182. 10.3389/fnbeh.2013.00182

21. Hossain MA: Effects of Uses and Gratifications on Social Media Use: The Facebook Case With Multiple Mediator Analysis. Emerald Publishing, Bingley, West Yorkshire; 2019. 10.1108/PRR-07-2018-0023

22. Leung L: Generational differences in content generation in social media: the roles of the gratifications sought and of narcissism. Comput Human Behav. 2013, 29:997-1006. 10.1016/j.chb.2012.12.028

23. Wang Z, Tchernev J, Solloway T: A dynamic longitudinal examination of social media use, needs, and gratifications among college students. Comput Human Behav. 2012, 28:1829-1839. 10.1016/j.chb.2012.05.001

24. Song I, LaRose R, Eastin MS, Lin CA: Internet gratifications and internet addiction: on the uses and abuses of new media. Cyberpsychol Behav. 2004, 7:384-394. 10.1089/cpb.2004.7.384 